\title{
Obowiązywanie prawa kościelnego w sumieniu w świetle nauczania Bernharda Häringa
}

Dyskusje toczące się wokół roli sumienia w życiu konkretnego człowieka i społeczeństwa rozgorzały szczególnie w XX wieku, w efekcie pojawienia się totalitaryzmów (w żaden sposób nie liczących się wszak z sumieniem jednostki) oraz rozwoju psychologii, która w rzeczywistości wiąże sumienie z superego. Głos w tej sprawie zabrał też Kościół w jednym z dokumentów soborowych, w którym uznaje on sumienie za „najtajniejszy ośrodek i sanktuarium człowieka, gdzie przebywa on sam z Bogiem, którego głos w jego wnętrzu rozbrzmiewa"'. Wobec propozycji afirmujących rolę sądu rozumu praktycznego warto przywołać również zgoła odmienne. Zdarzali się tacy, którzy wprost przestrzegali przed uznaniem sumienia za ostateczną rację ludzkiego postępowania. Carl Ellis Nelson prowokująco napisał w tytule swej książki: „Nie pozwól swemu sumieniu być twym przewodnikiem”2. Wiele wskazywać by też mogło, że tematem sumienia powinny

Sobór Watykański II, Konstytucja duszpasterska o Kościele w świecie współczesnym, Poznań 2002, nr 16.

2 C.E. Nelson, Don't Let Your Conscience Be Your Guide, New York 1978. 
zajmować się wyłącznie osoby związane z jakąś religią, tymczasem, jak zauważa ks. Andrzej Szostek, zdeklarowany ateizm nie przeszkodził Tadeuszowi Kotarbińskiemu w określeniu wierności swemu sumieniu fundamentem i drogowskazem stworzonej przez niego etyki niezależnej ${ }^{3}$. W świecie, w którym o autentycznej wolności mówi się i naucza niewiele, a za apogeum ludzkiej wolności uznaje się - jak bardzo trafnie ujęła to Naomi Klein możliwość wyboru między pepsi a coca-colą, sumienie ma szczególną rolę do odegrania ${ }^{4}$.

W pewien naturalny sposób miejsce po drugiej stronie barykady w stosunku do namysłu nad sumieniem zajmuje kościelne ustawodawstwo. Prawo, które zazwyczaj odbierane jest przez społeczeństwa jako ograniczenie wolności, w perspektywie wspólnoty wiary i modlitwy, która - jak sama uważa - kroczy ku pełni wolności, stało się w pewnym momencie dla niektórych wyłącznie przeszkodą, nadającą się tylko do obejścia lub ograniczenia, a docelowo zniesienia. Czy jednak prawo kościelne ma taki sam charakter jak prawo państwowe? Czy Kościół jest strukturą analogiczną do państwa? Czy można przejść obojętnie obok różnicy między tymi dwoma rzeczywistościami, która zasadza się na obecnym w Kościele dążeniu przede wszystkim do świata nieprzemijającego, stojącego ponad horyzontem doczesności?

3 Por. T. Kotarbiński, Zagadnienia etyki niezależnej, w: tenże, Pisma etyczne, red. P. Smoczyński, Wrocław 1987, s. 140-149, za: A. Szostek, Sumienie - prawda - prawo, „Znak” 1992, nr 11, s. 69.

Jak dodaje rozmówczyni wywiadu przeprowadzonego przez Macieja Kuźmicza: „W zamian za globalny świat (...) musieliśmy oddać wolność wyboru. (...) To, co wartościowe w kulturze, wybierają za nas stacje telewizyjne i studia filmowe”; M. Kuźmicz, Naomi Klein. Inteligentna złość, „Gazeta Wyborcza”, dodatek „Wysokie Obcasy” z 24 marca 2004, http:// www.wysokieobcasy.pl/wysokie-obcasy/1,96856,2030827.html?disableRedirects=true (dostęp: 11 stycznia 2018). 


\section{Etymologia terminu „sumienie”}

Narosła przez wieki wielość koncepcji sumienia, mnogość konotacji i prowadzące do szczególnego synkretyzmu znaczeniowego rozmycie wszelkich dotychczasowych definicji zmusza do namysłu nad zasadnością rozpatrywania zagadnień opartych na tym pojęciu ${ }^{5}$. Krótką analizę obecnej kondycji terminu „sumienie” Andrzej Szostek podsumowuje pytaniem: „Czy da się jeszcze sensownie mówić o sumieniu?"6. Odpowiadając twierdząco, zaznacza, że niezbędne do tego jest przyjrzenie się filozoficznemu ładunkowi tego pojęcia ${ }^{7}$. Filozoficzno-teologiczny „rodowód” sumienia jest, zdaniem polskiego etyka, o tyle istotny, o ile jego racjonalność jako sądu, wynikająca z poznawczej natury jego aktów, jest podstawą godności człowieka jako podmiotu ${ }^{8}$. Ostatecznie właśnie osoba - podmiot rozumnie poznający - może formułować sądy, w tym sądy sumienia, i to właśnie dlatego dotyczyć jej mogą zależności między sumieniem a prawem.

Istotny udział $\mathrm{w}$ ukształtowaniu się znaczenia pojęcia sumienia miał łaciński termin conscientia. Choć sam w sobie także zawiera on wieloznaczność ${ }^{9}$, nie sposób go pominąć. Bywa

$5 \quad$ Rzecz jasna, nie sposób przytoczyć wszystkich koncepcji sumienia ani badać ich zasadności; brak też tutaj miejsca na rozważenie współczesnych ciekawych i bardzo istotnych dyskusji opieranych na różnych koncepcjach, powodowanych nieraz przez konflikty prawne, do których doszło np. poprzez odwoływanie się do wolności sumienia.

A. Szostek, Sumienie..., dz. cyt., s. 70.

Tamże, s. 71.

8 Filozoficzna analiza sumienia przedstawiona jest w: T. Ślipko, Zarys etyki ogólnej, Kraków 2002, s. 366-370.

9 Oznacza ono bowiem tak czysto psychologiczną świadomość człowieka, jak i powszechne sądy moralne, a ostatecznie także konkretne sądy szczegółowe. Wzmianka o tym w: T. Ślipko, Zarys etyki ogólnej, dz. cyt., s. 360. 
często tłumaczony jako „świadomość, dosłownie jednak znaczy „współ-wiedza”. Istotnie, jest to, jak wskazuje Szostek, wyjątkowy typ wiedzy i wyjątkowe są jej odniesienia do innych rodzajów wiedzy. Co podkreśla były rektor KUL, jedno jest pewne: sumienie pojmowane jako typ wiedzy uwypukla w sposób zasadniczy „poznawczy charakter jego aktów”. Zaobserwowana kompatybilność w wyborze terminu określającego sumienie zdaje się świadczyć, zdaniem Bernharda Häringa, o tym, że odnoszący się do świadomości kognitywny rys jest dla niego znaczący, a poniekąd nawet najzwięźlej je definiujący ${ }^{10}$.

Wielość teorii sumienia, które można zaobserwować w rozważaniach Häringa, wynika z ich niekompletności. Przywołał on w Nauce Chrystusa kilka z nich, które posłużyły mu za tło dla przedstawienia własnej koncepcji, stanowiącej syntezę tomizmu i tradycji augustiańsko-franciszkańskiej.

Fakt wieloznaczności tego terminu, a także uwaga, że problem z perspektywy perypatetyków w istocie dotyczy rzeczy, a nie języka, również w: J. Krokos, Sumienie jako poznanie. Fenomenologiczne dopełnienie Tomaszowej nauki o sumieniu, Warszawa 2004, s. 154, przyp. 5 i 6.

10 Odnośnie do osobliwości tej wiedzy, jaką jest sumienie, krótkie rozważanie dotyczące niemieckiego Gewissen zamieszcza również A. Karaś. Prefiks ge-, analogiczny do łacińskiego con-, powoduje, że „sumienie (Gewissen) jest wiedzą (Wissen), poprzez którą wtajemniczony łączy się sam ze sobą. (...) Sumienie jest pokrewne refleksji, jest wiedzą pewną, bez wątpienia (...). Tego, co sumienie orzeka, nie da się podważyć”; zob. H. Kuhn, Sumienie pomiędzy wolnościa a prawem, w: Moralność chrześcijańska, red. L. Balter, K. Czulak, P. Góralczyk, S. Stancel, Poznań-Warszawa 1987, s. 61, za: A. Karaś, Człowiek u podstaw odnowy teologii moralnej w ujęciu Bernarda Häringa, Kraków 2009, s. 196, przyp. 32. 


\section{2. „Całościowa” teoria o sumieniu}

Znany niemiecki moralista w podejściu do sumienia kładzie akcent na całość, pełny obraz człowieka. Jego zdaniem, sumienie jest istotnie najgłębszym dążeniem człowieka do pełni i jedności. Jest domaganiem się pełnej życia syntezy między rozpoznaniem a miłowaniem, w którym zarazem wyraża się ostateczna tęsknota za miłosnym zjednoczeniem ze Źródłem wszelkiego dobra, prawdy i piękna, a także potrzeba jedności ze wspólnotą ludzką.

Häring przedstawił w Nauce Chrystusa „całościowe” ujęcie sumienia i poświęcił mu wiele uwagi $\mathrm{z}$ bardzo prostego powodu - sam był jego zwolennikiem. Dostatecznym wyjaśnieniem dynamiki sumienia jest dla niego uwzględnienie głębokiego zespolenia intelektu i woli, które wyraża nasze podobieństwo do Boga. Tak jak idealnie połączone są w Jednej Osobie: Miłujący-Poznający (Ojciec), Jego Poznanie (Słowo) oraz Jego Miłość (Duch Święty), tak i dusza ludzka, jako najlepszy obraz i podobieństwo Stwórcy, domaga się owej jedności, pragnie jej i dąży do niej ${ }^{11}$. W przypadku rozejścia się dążeń władz intelektualnych i wolitywnych człowieka (jako że są one skończone i ograniczone) dochodzi, zdaniem niemieckiego moralisty, do wielkiego, wewnętrznego rozdarcia podmiotu. Najdonośniejszy głos, wyrażający dziejącą się krzywdę, zdaje się podnosić sama głębia duszy, która, stanowiąc podstawę i punkt wyjścia dla jedności duchowej, doznaje naruszenia przez rozbieżność duchowych władz. To właśnie w takim przypadku, konkluduje Häring, upatrywać trzeba pierwotnego, jeszcze nieświadomego bólu sumienia. Barwnie opisuje on ów stan językiem teologii: „Obraz

11 B. Häring, Nauka Chrystusa. Zasadnicza postać chrześcijańskiego życia, t. I, Poznań 1962, s. 160-161. 
Trójcy Świętej cofa się z lękiem przed niebezpieczeństwem utraty podobieństwa"12.

Według Häringa, sumienie chrześcijanina, poza swymi naturalnymi funkcjami, otrzymuje nadprzyrodzone zadanie, któremu towarzyszy zarazem nadprzyrodzona moc. Jako źródło tego zadania wskazuje on nadnaturalne objawienie w Chrystusie i prowadzenie przez Ducha Świętego. Zobowiązują one sumienie chrześcijanina do słuchania Słowa i posiłkowania się wzorem życia Chrystusa, upominając zarazem, że powinien on być uległy wobec natchnień pochodzących od Ducha Świętego. Jak twierdzi niemiecki moralista, Bóg wpływa na nasze sumienie poprzez dary właściwego wyczucia, subtelności, wrażliwości i uzdalnia tym samym do wyraźnego poznania i odczytania swojej woli zawartej tak w Jego objawieniu, jak i w okolicznościach, które są naszym udziałem ${ }^{13}$. Poprzez współpracę z łaską i naśladowanie Chrystusa sumienie chrześcijanina staje się coraz wnikliwsze. Zdaniem Häringa, woła ono do nas nie własnym słowem, ale głosem Chrystusa, rozświetlającym je niczym płomień świecę ${ }^{14}$.

Z drugiej strony, chociaż wołające sumienie pozwala człowiekowi usłyszeć głos nie tylko swój, ale również Najświętszego Boga, to jednak, jak zaznacza Häring, nie każdy osąd sumie-

12 Tamże, s. 161. Podobny obraz autor maluje w takiej oto wypowiedzi: „Sumienie jest obrazem Bożym duszy, która broni się przed odejściem od dobra i od Boga"; B. Häring, Skrupulosität, Gewissen und Verantwortung, „Anima” 11 (1956), s. 41, za: A. Karaś, Człowiek u podstaw odnowy teologii moralnej..., dz. cyt., s. 198.

13 B. Häring, Nauka Chrystusa, dz. cyt., t. I, s. 165.

14 Tamże, s. 155. 
nia umożliwia jednoznaczne upatrywanie w nim głosu Boga ${ }^{15}$. Podkreśla przy tym, że działanie Boże poprzez przyczyny drugorzędne wcale nie powinno skutkować pomniejszaniem przez nas Jego działania. Nadto taki sposób Bożego postępowania bynajmniej nie powoduje, że obowiązuje nas ono w mniejszym $z_{\text {zakresie }}{ }^{16}$. Nawet jeśli w osądzie sumienia nie słychać wprost głosu Boga, to jednak można twierdzić, że jest ono faktycznie Jego głosem. Häring dodaje przy tym, że nieodzowny jest nasz wkład i trud w wypracowanie słusznego osądu sumienia. „Sumienie jako uzdolnienie, które pobudza nas, byśmy postępowali według naszego zapatrywania, jest zawsze głosem. Ale osąd sumienia, który odchyla się od słusznego, złotego środka, jest naszym (oczywiście błędnym) dziełem”.

\section{Prawo Kościoła zwykłym prawem społeczności?}

By przyjrzeć się zależnościom zachodzącym między sumieniem a prawem, zwłaszcza sumieniem katolika a prawem kościelnym, trzeba wpierw omówić samo prawo kościelne.

Polski kanonista ks. Remigiusz Sobański refleksje w tej materii opiera na rozumieniu Kościoła jako wspólnoty ludzi złączonych

15 A. Szostek bardzo wyraźnie zaznaczał, że sumienie jest „moje” i trudno przypisywać jego sądy komuś innemu; zob. A. Szostek, Sumienie..., dz. cyt., s. 73-74.

16 Do zobrazowania tego zdania Häring podaje przykład wzięty $\mathrm{z}$ historii myśli teologicznej - choć teologowie w średniowieczu uważali, że Bóg wprawia w ruch ciała niebieskie za pomocą aniołów, to ostatecznie w Stwórcy widzieli przyczynę ich przemieszczania się. Poznawszy prawa natury, według których Najwyższy kieruje światem, wcale nie oddaliliśmy się od Boga w porównaniu z czasem, kiedy ich nie znaliśmy. 
przez jedną wiarę. To spojrzenie rozszerza nieco jego włoski kolega, Libero Gerosa, twierdząc, że jako punkt wyjścia do wszelkich rozważań dotyczących prawa Kościoła trzeba przyjąć, iż jest ono prawem szczególnego rodzaju, i w związku z tym nie widzi on możliwości upodobnienia go do prawa świeckiego ${ }^{17}$.

\subsection{Przeszłość}

Analizując uwarunkowania historyczne, Sobański stwierdził, że niegdyś, choć uznawano Kościół za rzeczywiście społeczność religijną, założoną przez Boga, to jednak składającą się z ludzi i jako taką potrzebującą swojego prawa, wedle zasady: ubi societas, ibi ius. W praktyce oznaczało to chęć tworzenia, rozpatrywania i interpretacji prawa Kościoła według wzorców prawa świeckiego, w przekonaniu, że podlegają one identycznym mechanizmom działania. Pociągnęło to za sobą poważne konsekwencje. Jak wskazuje Sobański, prawo pojmowano jako środek pozwalający na utrzymywanie porządku i dyscypliny. Nic więc dziwnego, że w taki sposób je formułowano. Kościół natomiast w myśl tego rozumiał siebie jako społeczność uporządkowaną i zaradnie funkcjonującą. Skutki takiego podejścia znalazły odbicie w postawie drugiej strony, tj. podlegających prawu.

Skoro prawo zmierzało do zachowania społecznego porządku, który przecież ma charakter zewnętrzny, to cel, jakim jest przestrzeganie prawa, mógł zostać łatwo spełniony właśnie wtedy, kiedy ów porządek był zachowany ${ }^{18}$. Nacisk położony na przestrzeganie norm pociągnął za sobą daleko idące konsekwencje. W taki sposób, jak wskazuje Sobański, doszło do przyjęcia przez

17 L. Gerosa, Prawo Kościoła, Poznań 1999, s. 15.

18 R. Sobański, Kościót - prawo - zbawienie, Katowice 1979, s. 55. 
wielu wiernych postawy legalistycznej, albowiem prawo nie miało już w ich oglądzie rzeczywistości odniesienia do zbawienia. Problem w tym, że wskutek tego procesu „porządek prawny i porządek zbawienia zostają oddzielone"19. Ostatecznie, jak stwierdza kanonista, Kościół wpadł w wir różnych prądów ideowych, które przedstawiały go na sposób właściwy państwu.

\subsection{Propozycja Klausa Mörsdorfa}

Uważany do swej śmierci za autorytet w dziedzinie prawa kanonicznego prof. Klaus Mörsdorf opublikował w latach 50. i 60. prace, w których utrzymywał, że kanonistyka powinna unaoczniać obecność wymiaru prawnego, zawartego już w samych strukturach, które Chrystus wykorzystał do zbudowania Kościoła, jak również wykazywać, że zasada prawna uwzględniona jest już w częściach składowych ekonomii zbawienia: „Prawna struktura Kościoła jest wbudowana w jego boskie pochodzenie, w Człowieka - Boga i w Jego świętą władzę wypełnianą przez Niego w Kościele"20.

Opierając się właśnie na przekonaniu, że temat prawa kanonicznego zakorzeniony jest w samym pojmowaniu misterium Kościoła, Mörsdorf podjął rozliczne próby chrystologicznej interpretacji prawa kanonicznego. Eklezjologiczny most (stanowiący regułę definiującą strukturę Kościoła) wzniesiony przez niemieckiego kanonistę, łączący brzegi Wcielenia i kościelnego porządku prawnego, oparty jest na dwóch filarach: słowie i sakramencie. Traktuje on je jako pierwsze, zasadnicze i niepochodne

19 Tamże, s. 54.

20 K. Mörsdorf, Lehrbuch des Kirchenrechts auf Grund des Codex Iuris Canonici, t. I, Paderborn 1959, s. 13, za: L. Gerosa, Prawo Kościoła, dz. cyt., s. 35. 
części składowe Kościoła, stwierdzając wyraźnie: „Słowo i sakrament są dwoma różnymi, ale wzajemnie powiązanymi elementami konstrukcji widzialnego Kościoła”21.

Jak wykazuje Mörsdorf, Apostołowie dostrzegają prawny charakter wymagań stawianych przez słowo Pana, którego stali się przekazicielami, albowiem zostali do tego bezpośrednio wezwani przez Jezusa i występują jako wyznaczeni przedstawiciele mający pełnię władzy. W efekcie również słowo kierowane przez biskupów domaga się posłuszeństwa i ma charakter prawny, gdyż głoszone jest w imię Pana. Ta nieodłączna i wiążąca moc jest też zawarta w znaku sakramentalnym. Wspólnym korzeniem słowa i sakramentu jest dla kanonisty sam Chrystus, który, tworząc sakramenty, przyznał im osobne znaczenie oraz skuteczność. Dzięki zwięzłemu połączeniu symbolu prawnego i sakramentu Mörsdorf, jak zauważa Libero Gerosa, otworzył sobie drzwi do uargumentowania prawnej natury sakramentalnej struktury Kościoła, jak również jego niepowtarzalności w porównaniu z prawodawstwem państwowym.

\subsection{Kościół jako misterium}

Analizując tezę tożsamości Kościoła struktur i Kościoła łaski, Remigiusz Sobański zwrócił uwagę na jedność Kościoła, w którym $z$ jednej strony istnieje i obowiązuje prawo, a z drugiej głoszona jest Ewangelia i praktykowana modlitwa. Polski kanonista zaznaczył, że sposób rozumienia wspólnoty wierzących jako tajemnicy znajduje odbicie również w posoborowej kanonistyce.

21 K. Mörsdorf, Zur Grundlegung des Rechtes der Kirche, „Münchner Theologische Zeitschrift” 3 (1952), s. 330, za: L. Gerosa, Prawo Kościoła, dz. cyt., s. 35. 
Jak odnotowuje, próba takiego spojrzenia na Kościół stała się z początku powodem pewnej irytacji sporej części ojców soborowych, dziwiących się, że wspólnota powierzona im i zarządzana przez nich na co dzień jest w pierwszej kolejności misterium $^{22}$. Podobne reakcje dały się zauważyć np. wśród kanonistów. Dostrzegł je również Josef Ziegler, niemiecki teolog zajmujący się powiązaniami między prawem i sumieniem. Stwierdził on, że niektóre ostre reakcje znawców prawa Kościoła po soborze pozwalają przypuszczać, że nieszczególnie byli oni zadowoleni z przypisania ich dyscyplinie docelowo funkcji służebnej ${ }^{23}$. Ich protest, w ocenie Zieglera, toruje drogę biegnącą nie tyle od prawa ku błędnie pojmowanej wolności, czego się obawiano, ile właśnie od prawa do sumienia.

We współcześnie postulowanej reorientacji kanonistyki najistotniejsza jest, zdaniem Sobańskiego, zmiana świadomości prawnej samych wiernych, która miałaby pójść w kierunku dostrzegania przez nich przede wszystkim zbawczego wymiaru prawa, a nie tylko jego porządkowego charakteru. Choć pełni ono również taką funkcję i niewłaściwe byłoby jej deprecjonowanie, to jednak nacisk powinien być położony właśnie na aspekt soteryczny. Na horyzoncie widnieje prawo, którego celem jest zbawienie człowieka - inne nie ma w Kościele racji bytu. Dlatego też $\mathrm{w}$ owym procesie zmian potrzeba przede wszystkim zmiany w spojrzeniu na Kościól, który trzeba rozumieć nie tylko jako pewną społeczność, ale poprzez kompletność jego tajemnicy ${ }^{24}$.

\footnotetext{
22 R. Sobański, Kościół - prawo - zbawienie, dz. cyt., s. 60.

23 J. Ziegler, Vom Gesetz zum Gewissen, Freiburg im Br. 1968, s. 238.

24 R. Sobański, Kościół - prawo - zbawienie, dz. cyt., s. 62.
} 
Wobec różnych zarzutów wysuwanych względem kierunku zmian soborowych Ziegler dobitnie stwierdza, że błędem byłoby mówienie o porzuceniu „Kościoła prawa” na rzecz „Kościoła miłości”, czy, jak wolałby Sobański, Kościoła łaski. Nie dostrzega on bynajmniej zerwania ciągłości życia Kościoła. Przyznaje jednak, że w miejsce zewnętrznej integralności postępowania zdecydowano się kłaść coraz większy nacisk na zintegrowanie personalne, tak że autorytet ustąpił przed solidarnością, uniformizacja przed różnorodnością, a instytucja przerodziła się w reflek$s_{j} e^{25}$. Pojawiające się przy tym drugoplanowe trudności, które, zdaniem Zieglera, są do uniknięcia, opatrzone zostały przez niego komentarzem $\mathrm{w}$ formie przywołanej wypowiedzi Josepha Ratzingera:

Wtórną, przez siebie wywołaną i w sposób zawiniony skandaliczną sytuacją jest, kiedy pod pretekstem obrony praw Boga zostaje umocniona określona sytuacja społeczna i zdobyta w niej pozycja władzy. Wtórną, przez siebie wywołaną i w sposób zawiniony skandaliczną sytuacją jest, kiedy pod pretekstem ochrony depozytu wiary i jego niedającej się zmienić natury broni się własnego wczoraj: nie samej wiary, która istniała na długo przed owym wczoraj i jego formami, ale broni się właśnie tej formy, którą wiara wytworzyła w efekcie uprawnionych, zgodnych $\mathrm{z}$ duchem czasu prób nawiązania kontaktu z konkretną epoką, a która to forma obecnie się przestarzała i w żaden sposób nie ma prawa wysuwać roszczeń do wiecznego trwania ${ }^{26}$.

25 Tamże, s. 239.

26 J. Ratzinger, Der Katholizismus nach dem Konzil (referat wygłoszony podczas 81. Dnia Katolików Niemieckich w Bambergu w 1966 roku), „Herder-Korrespondenz" 20 (1966), s. 351; za: J. Ziegler, Vom Gesetz zum Gewissen, dz. cyt., s. 238. 


\section{Stopniowalność prawa Kościoła a zobowiązanie do posłuszeństwa mu}

Wątpliwości dotyczące stopniowalności prawa Kościoła miał rozwiać list apostolski Jana Pawła II Ad Tuendam Fidem, który omawia tę tematykę na podstawie tekstu wyznania wiary, opartego na Symbolu nicejsko-konstantynopolitańskim. Prócz Symbolu dokument zawiera trzy akapity doprecyzowujące układ prawd wiary katolickiej, do których przylgnąć mają wierni. To właśnie w nich zawarte są istotne wskazania przedstawiające hierarchię tych prawd, a także sposób, w jaki zobowiązują one wierzącego do przyjęcia ich jako integralnie przynależące do treści jego aktu wiary. Warto przytoczyć tu wypowiedź Bernharda Häringa, który zaznaczył, że zasadne jest ustalenie przez naukę wiary poszczególnych stopni pewności wobec różnych tez ${ }^{27}$.

Poszczególne stopnie zgody wiary, będące niczym innym jak przejawem eklezjalnego posłuszeństwa, do którego wierni są obligowani prawnie względem nauczania Magisterium, zostały poruszone w każdym z akapitów Ad Tuendam Fidem. W celu uzyskania szerszej perspektywy powróćmy do myśli Häringa. Stwierdza on, że decyzje podejmowane w Kościele cieszą się zasadniczo większym stopniem obiektywności aniżeli sąd pojedynczego uczonego ${ }^{28}$. Niemiecki moralista utrzymuje, iż Kościół ma uzasadnione prawo być przekonanym, że również $\mathrm{w}$ orzeczeniach, które nie są nieomylne, cieszy się większym wsparciem i opieką Świętego Ducha niż poszczególny teolog. Ze względu na to uczony o odmiennym zdaniu musi nieraz pokornie uznać swą

27 B. Häring, Nauka Chrystusa, dz. cyt., t. I, s. 63.

28 Tenże, Nauka Chrystusa, t. II, tłum. i oprac. J. Klenowski, Pallottinum, Poznań 1962, s. 64. 
podległość wobec decyzji wydanych przez kompetentne instytucje Kościoła.

Jednak i tu Häring nie waha się zwrócić uwagi na wątki trudne, mianowicie na sytuacje, kiedy okazuje się, że jakieś orzeczenia papieskich komisji były nieprawdziwe lub niewystarczające. Czasem bowiem decyzje, które zdawały się dotyczyć nauki wiary, później objawiały się jako dyscyplinarne ${ }^{29}$. W przypadku zarządzeń o tym charakterze, zdaniem Häringa, powinnością danego teologa jest pełne podporządkowanie się im, jak również pełne czci badanie wysuniętych argumentów. Jeżeli natomiast jakaś nauka zostałaby przez władze Kościoła odrzucona, to jakikolwiek bunt wobec tej decyzji moralista z Böttingen nazywa grzesznym i wskazuje, że w takiej sytuacji trzeba a priori zakładać, że osąd kompetentnej władzy został podjęty na drodze wyważonej refleksji, zatem należy uznawać go za słuszny dopóty, dopóki wyraźne kontrargumenty nie wskażą czegoś zupełnie przeciwnego. Kazus teologa, którego tezy stoją w sprzeczności z orzeczeniem komisji papieskiej, Häring tłumaczy następująco: taki uczony powinien poddać rewizji przede wszystkim samego siebie - a zwłaszcza to,

29 Autor podał przykład orzeczenia tuto doceri non potest, a więc sytuacji, gdy zachodzą istotne powody, by danej nauki w konkretnych okolicznościach nie wygłaszać, a jeśli już się ją wykłada, to jako hipotezę, z jasnym zaznaczeniem, że nie wysuwa ona żądań poza swój faktyczny zasięg, poza to, czym w istocie jest. Jeżeli po upływie jakiegoś czasu owa hipoteza bardziej przystosuje się do systemu prawd wiary, a przede wszystkim nie będzie postrzegać siebie samej jako przeciwną objawionej lub pewnej wykładni Kościoła, to Häring uważa za możliwą utratę zasadności orzeczenia Kościoła - a więc zarazem i jej ważność. Niemiecki teolog zaznacza przy tym wyraźnie, że pogląd oparty na nieuzasadnionych wnioskach i ich konsekwencjach, jeżeli sprawia wrażenie niezgodności z nauką Kościoła, może być jak najbardziej zakazany. Do czasu oczyszczenia danej hipotezy z nieprawdziwych założeń i niebezpiecznych skutków nie można jej wykładać; zob. B. Häring, Nauka Chrystusa, dz. cyt., t. II, s. 64-65. 
czy jego podejście do głoszenia własnych poglądów nie stało się niebezpieczeństwem dla poprawnego rozumienia wiary bądź czy nie zagroziło zbłądzeniem słabym w wierze ${ }^{30}$.

\subsection{Specyfika prawa Kościoła}

Prawo Kościoła jest, zdaniem moralisty z Böttingen, zakorzenione w ostatecznym Źródle wszelkich praw, czyli Bogu ${ }^{31}$. Nie uważa on jednak prawa ludzkiego za zbędne. Jeżeli sam Pan przekazał nas Kościołowi i prawodawstwu w nim stanowionemu, a w rzeczywistości świeckiej prawu, które regulowane jest przez państwo, to posłuch okazywany Kościołowi oznacza posłuch wobec Chrystusa. Zasadności posłuszeństwa cywilnym i religijnym normom prawnym Häring upatruje przede wszystkim w doskonałym wypełnianiu wszelkiego prawa moralnego przez Chrystusa w trakcie Jego życia aż do śmierci ${ }^{32}$. Fakt ten postrzega on jako

30 Tylko w sytuacji, gdy dany uczony doszedłby do pewnego przekonania, że dalsze obstawanie przy zaskarżonym poglądzie będzie przemawiało na korzyść wiary, jej ochrony i pobożności, mógłby nadal publicznie go przedstawiać i bronić. Przypuszczalnie formą tej obrony mogłoby być przedstawienie swoich poglądów inaczej, z wykazaniem, że w trakcie prowadzonych analiz powstały nowe sposoby ujęcia danego zagadnienia, zapewne nieznane do tej pory Magisterium Kościoła. Starając się zachować ducha wspólnoty, taki autor powinien jednak stawiać swą tezę z „należytą skromnością jako zagadnienie, jako problem, a nie zaciekle bronić swego poglądu"; B. Häring, Nauka Chrystusa, dz. cyt., t. I, s. 265.

31 Tamże.

32 Nie pozostawia on tego sformułowania bez przykładu. Taką postawę Chrystusa dostrzega, gdy: uiszcza On należne podatki, uczestniczy w nakazanych świętach w Jerozolimie, praktykuje szabat (jak zauważa Häring - nie według literalnej i ostatecznie bezdusznej interpretacji faryzeuszy). Szanował On autorytet władzy cywilnej do tego stopnia, że poddał się wyrokowi śmierci. Mimo to nie wahał się jednocześnie wprost punktować niesprawiedliwości, czy to przed Piłatem, czy Sanhedrynem. Wielokrotnie 
normatywny również dla chrześcijan. Prezentując takie stanowisko, niemiecki redemptorysta przekonuje, że ta postawa Chrystusa nie wypływała ani z naiwności, ani z niemocy. Wręcz przeciwnie, Jezus z Nazaretu dobrze wiedział z bolesnej autopsji, jak ułomna jest duchowna i świecka władza człowieka. Nikt inny nie doświadczył tak bardzo jak On wewnętrznej dysharmonii między pozorną i faktyczną sprawiedliwością. A jednak wbrew przeciwnym przesłankom nie zakończył On epoki prawa stanowionego przez ludzi. Swoim Apostołom i wszystkim, którzy mieli po nich nastąpić, zlecił władzę prawodawczą. Mimo że, w porównaniu z prawem Bożym, prawa ludzkie nie cieszą się taką klarownością i nie zapewniają osiągnięcia dobra w sposób równie absolutny jak ius divinum. Ułomność czy niedoskonałość prawa stanowionego przez władzę kościelną, doświadczana przez wszystkich, którzy pragną go przestrzegać, jest zatem wpisana w jego istnienie i obowiązywanie.

Ciężar ułomności prawa ludzkiego niemiecki moralista wiąże z cierpieniem Chrystusa i z krzyżem, którego On nie odrzucił. Posłuszeństwo Jezusa aż do śmierci niezwykle rozjaśnia, jego zdaniem, kwestię obowiązywalności ludzkiego autorytetu. Jak utrzymuje, zgoda Pana na mord dokonany w imię prawa uświęciła podległość wobec (nieraz bardzo ostrego) prawa ludzkiego. Stanowi ona drogę podjętą przez Chrystusa i przez Niego uświęconą.

Häring był przekonany, że człowiek potrzebuje prawa ludzkiego ze względu na swą społeczną naturę. Co więcej, autorytet władzy i prawa przez nią stanowione są konieczne do jego

krytykował też wąskie stosowanie prawa przez faryzeuszy. Nie zaprzestał jednak słuchać władzy cywilnej tam, gdzie mógł to czynić zgodnie z wolą Ojca. 
moralnego wzrostu. Bez prawa obejść się nie może nie tylko jednostka, ale także całe społeczeństwo. Jako szczególny powód istnienia ludzkich regulacji prawnych jawił się moraliście z Böttingen grzech pierworodny. Bez ograniczeń hamujących niewłaściwe posługiwanie się wolnością „złych” „dobrzy” w krótkim czasie tracą autentyczną wolność wyboru dobra właśnie ze względu na uwodzenie i przemoc, które płyną od złych ${ }^{33}$.

\subsection{Prawo warunkiem wzrostu chrześcijanina w doskonałości}

Oprócz wymiaru krzyża, jaki dostrzega w ludzkim prawie Häring, stanowi ono również pewną drogę ku sprawiedliwości, realizację ładu Bożej mądrości, rezultat miłości urzeczywistnianej przez społeczność i dla niej. Starając się dostrzec pozytywne skutki posłuszeństwa okazywanego ułomnemu prawu ludzkiemu, teolog zauważa, że prowadzi ono do poszukiwań właściwych, zasadniczych źródeł dobra, do których podprowadzić może jedynie ludzkie prawo. Ból i rozczarowanie związane z doświadczeniem jego ograniczoności zmusza chrześcijanina, by $\mathrm{w}$,Zwierciadle doskonałego prawa miłości szukał drogi do zjednoczenia się z Chrystusem" 34 .

33 Mówiąc o uwodzeniu i przemocy, autor zdaje się mieć na myśli gorszący wpływ „złych” na „dobrych”. Komentarz autora do tego stwierdzenia daje bardzo dużo do myślenia w obecnym kontekście polityczno-społecznym, uwzględniając zmiany, jakie nastąpiły w ciągu półwiecza od napisania tekstu. Häring dodaje bowiem, że właśnie wypaczone rozumienie wolności, pociągające ludzi prawych na ścieżkę wyborów moralnie złych, jest największym błędem popełnianym przez zachodnie demokracje; zob.

B. Häring, Nauka Chrystusa, dz. cyt., t. I, s. 266.

34 Tamże, s. 267. 


\subsection{Obowiązywanie praw słusznych}

Jeżeli chodzi o podstawę praw wiążących w sumieniu, to zdaniem Häringa, jest nią zakotwiczona w samym ich wnętrzu słuszność prawna, bez względu na to, czy chodzi o prawo podmiotowe czy moralne.

Rozwijając wątek moralistyczny, Häring nie do końca przyznaje rację tym, którzy twierdzą, że ustawodawca poprzez uciekanie się wyłącznie do kar nie chce łamać sumienia jednostki. Przypomina zasadę, że już związanie sankcji karnej z ustawą jest oznaką szczególnej troski prawodawcy o określaną owym przepisem rzeczywistość.

W przypadku zawinionego przekroczenia słusznego przepisu nasz teolog dostrzega obowiązek w sumieniu przyjęcia kary związanej z daną regulacją prawną. Warunkiem zaistnienia słusznej kary jest, według niego, wzięcie pod uwagę roli prawa wobec dobra ogólnego, a także, na ile to możliwe, uwzględnienie stopnia winy i wychowawczych skutków kary.

Ten sposób podejścia należy, zdaniem moralisty z Böttingen, stosować również wobec tzw. lex mere poenalis, czyli prawa wydanego przez prawodawcę $\mathrm{z}$ zastrzeżeniem wyłącznej obowiązywalności zewnętrznej (są to zatem przepisy, które nie mają mocy wiążącej wobec sumienia). Ich istnienie budzi jego wątpliwości dlatego, że jeśli przepis nie obowiązuje w sumieniu, to de facto w ogóle nie obowiązuje. A jednak obok prawa, z którym wiąże się moc obowiązywania, istnieją także regulacje o charakterze podpowiedzi i życzeń prawodawcy, nałożone na podwładnego z zamiarem ukazania mu celu prawa. Wszystko po to, by podmiot dążył do owego celu, bądź to ze względu na niego samego, bądź na wydane wskazówki. Przykładem takich ustaw są reguły zakonne, które mimo wszystko mają swoje moralne znaczenie 
i tylko poważny motyw o charakterze moralnym mógłby, zdaniem Häringa, stanowić przesłankę do pominięcia ich lub niezwrócenia na nie uwagi ${ }^{35}$.

Ostrych słów krytyki Bernhard Häring nie szczędził także teorii mówiącej jedynie o obowiązku przyjęcia kary, zgodnie z którą podlegający prawu mógłby, zachowując wolność od winy, dokonać wyboru między wykonaniem prawa a przyjęciem grożącej kary. W przekonaniu niemieckiego moralisty teza ta jawi się wręcz jako zupełnie fałszywa i w tym przypadku nie może być mowy o słusznej karze ${ }^{36}$. Autor Nauki Chrystusa uważa, że „gdzie świadczenie nie obowiązuje, tam jego odmowa nie jest winą, a gdzie nie ma winy, tam kara nie ma sensu lub jest niesłuszna”37. Ewentualne rozwiązanie stanowiłyby „zarządzenia wychowawcze”, niemające wymiaru karnego. Ich zasadność stawia on jednak

35 To bardzo ciekawe, wieloaspektowe zagadnienie. Jak zapisano w prologu do konstytucji Zakonu Kaznodziejskiego: „Ut igitur unitati et pacitotius Ordinis promoveamus, volumus et declaramus ut constitutiones nostrae non obligent nos ad culpam sed ad poenam, nisi propter praeceptum aut contemptum”. Ciekawy komentarz do tego zapisu, autorstwa Humberta z Romans, przywołuje Edward T. Dunn: „Ci, którzy są delikatnego sumienia, unikaliby prawdopodobnie naruszania konstytucji, gdyby były one obciążone sankcjami zarówno grzechu, jak i kary, ale szkoda i niewygoda, które powstałyby w efekcie tego dla całej wspólnoty, nie mogłyby być usprawiedliwione nieznacznym postępem w wierności w przypadku kilku osób. Stąd ten rodzaj obowiązywalności jest najroztropniejszy, ponieważ lepiej jest, gdy naruszane są zarządzenia ludzkie aniżeli Boże"; E.T. Dunn, In Defense of The Penal Law, Woodstock 1957, http://cdn.theologicalstudies.net/18/18.1/18.1.3.pdf (dostęp: 13 stycznia 2018), s. 57.

36 Jeśli chodzi o Häringową ocenę tej teorii z uwzględnieniem jej tła historycznego, to wypada ona o wiele łagodniej - stanowiła pewną próbę ochrony sumienia wierzących przed ustawicznym lękiem wobec grzechu i nadmiernym obciążeniem pozytywnymi przepisami.

37 B. Häring, Nauka Chrystusa, dz. cyt., t. I, s. 269. 
również pod znakiem zapytania - jeśli pewne sprawy mają z założenia nie być obowiązkowe, to w imię czego trzeba tak szybko do nich wychowywać? ${ }^{38}$

Jednak co z prawem, którego nie można wypełnić z powodów moralnych lub fizycznych? Czy zaniedbanie takich regulacji skutkuje zaciągnięciem winy? Namysł nad prawem niemożliwym do wykonania prowadzi Häringa do wniosku, że w tej sytuacji ono nie obowiązuje. Czyni on przy tym ważne, jak się zdaje, zastrzeżenie. Mianowicie stwierdza, że słuszność istotnej części danego prawa i możliwość spełnienia go skutkuje obowiązywaniem tej właśnie istotnej części. I tak, brak możności uczestnictwa w całej Eucharystii nie zwalnia z obecności choćby na jej części, aczkolwiek musi to być część istotna. Obowiązek zostaje zatem zawężony, ale nie zniesiony. Z drugiej strony, możliwość wypełnienia nieistotnej części regulacji prawnej wiedzie do ustania obowiązywania - o ile nie da się go podzielić na mniejsze części ${ }^{39}$.

Modyfikacje prawa polegające na zmianie przepisów poprzez zastąpienie ich innymi, co dokonało się choćby w przypadku postu eucharystycznego ${ }^{40}$, lub też odwołanie prawa, czego przykład stanowi zastąpienie starotestamentowych przepisów rytualnych

38 Jak wyjaśnia niemiecki moralista, nakładane przez reguły zakonne praktyki pokutne czy związane ze wzrostem w pokorze są czymś innym. Ich celem nie jest kara.

39 Przypadku podziału jakiegoś świadczenia na części i obowiązywalności wówczas którejś z nich Häring nie opatruje żadnym konkretnym przykładem mogącym zilustrować taką sytuację.

40 Paweł VI, Rescriptum, AAS 57 (1965), s. 186. Zob. także M. Pastuszko, Post eucharystyczny, http://bazhum.muzhp.pl/media//files/Prawo_Kanoniczne _kwartalnik_prawno_historyczny/Prawo_Kanoniczne_kwartalnik_prawno_ historyczny-r1986-t29-n1_2/Prawo_Kanoniczne_kwartalnik_prawno_ historyczny-r1986-t29-n1_2-s185-2017Prawo_Kanoniczne_kwartalnik_ prawno_historyczny-r1986-t29-n1_2-s185-201.pdf (dostęp: 13 stycznia 2018). 
przez nowe prawo wolności w Chrystusie, ostatecznie usuwają słuszność prawną takich przepisów i skutkują ich nieobowiązywaniem. Ponadto, jak wskazuje Häring, także prawo nakazujące coś moralnie negatywnego (np. rasistowskie ustawy legalizujące faktyczną eksterminację ludzi), jak i coś niemożliwego do wykonania (choćby zobowiązanie do uczestnictwa we Mszy św. przez chorego) są niesłuszne i nie obowiązują w sumieniu $\mathrm{z}$ tego powodu, że brak im owej wewnętrznej podstawy słuszności ${ }^{41}$.

Natomiast, zdaniem redemptorysty, żądania idące w stronę tego, co złe samo w sobie, powinny skutkować, nie uwzględniając nawet zagadnienia niesłuszności, odmową posłuszeństwa, postawą biernego oporu, zatem niewykonaniem ustawy. Jednak za nieproporcjonalny do tego typu regulacji uznaje on opór czynny, objawiający się buntem czy też rewolucją.

Wyłącznie wtedy, gdy władza nie cieszy się odpowiednią legitymizacją bądź gdy jej poczynania zmierzają w stronę destrukcji moralnego porządku, czego przykładem jest dla moralisty z Böttingen dwanaście lat hitlerowskich Niemiec, można przejść do czynnego oporu. Jak wskazuje, nie wszystkie prawa, które w swej istocie zwracają się przeciw prawu moralnemu, sankcjonują stosowanie czynnego oporu w stosunku do ustawodawcy. Ponadto taki rodzaj przeciwdziałania należy, jego zdaniem, warunkować dwojako: czynny opór dopuszcza on wówczas, kiedy istnieje nadzieja na normalizację stosunków w wyniku jego zastosowania i zarazem nie doprowadzi to do "gorszego zła”42.

41 B. Häring, Nauka Chrystusa, dz. cyt., t. I, s. 271.

42 Poza odwołaniem się do warunków polityczno-społecznych otwierających drogę do zastosowania czynnego oporu (rzeczywistość III Rzeszy) autor nie podaje żadnego przykładu "gorszego zła”, które w pewnych przypadkach miałoby spowodować czynny opór, ani też nie przybliża, na czym 


\subsection{Obowiązek podlegania prawu ze względu \\ na dobro wspólne}

Przypadek istnienia prawa niesłusznego (choćby odwołanego), którego wykonywanie jest samo w sobie moralnie obojętne albo dobre, skłania Häringa do stwierdzenia, że takie prawo nie obowiązuje ${ }^{43}$. Jednak ze względu na ład publiczny, zapobieżenie zgorszeniu, właściwie ukształtowaną miłość własną, uniknięcie znacznego niepokoju wewnętrznego czy też większej kary ${ }^{44}$ zachodzi $\mathrm{w}$ sumieniu zobowiązanie do zachowania prawa. Podobnie właściwie ukształtowana miłość własna, obligująca do wystrzegania się większych szkód i kar, wiązała, zdaniem Häringa, w czasie okupacji, dlatego też zarządzenia wydane przez okupanta, jeżeli nie były same w sobie moralnie złe, powinny być zachowywane.

\subsection{Stopień i rodzaje obowiązywania prawa ludzkiego}

Häring utrzymuje, że pod karą grzechu ciężkiego, a zatem poważnie, obowiązuje takie prawo, które samo w sobie, ze względu

miałaby polegać normalizacja stosunków, do której ów opór miałby dążyć; zob. tamże.

43 Podkreśla on przy tym wyraźnie, że chodzi o prawo samo w sobie. Ocenę zmienia wzięcie pod uwagę perspektywy sumienia.

44 Jak wskazuje autor, dla chrześcijan bardzo jasnym przykładem może być postawa św. Pawła. Apostoł Narodów, mimo odwołania przepisów zabraniających spożywać mięso z ofiar składanych bożkom, postanowił, że sam nie będzie go spożywał ze względu na braci. Paweł uważał też, że można posiadać wiedzę o pewnych regulacjach prawnych i zaprzestaniu ich obowiązywalności, ale tym, co liczy się przede wszystkim, jest miłość. Jej brak prowadzi do grzechu przeciw braciom i ,urażenia” ich słabych sumień, zatem ostatecznie jest to również grzech przeciw Chrystusowi. Wobec często powtarzanego hasła „wszystko mi wolno" warto przytoczyć powracającą niczym echo drugą część tego Pawłowego zdania: „nie wszystko przynosi korzyść"; por. 1 Kor 6, 12. 
na postulowany cel bądź w związku z wyjątkowymi czynnikami, ma przemożne znaczenie dla dobra powszechnego lub ochrony dobra prywatnego. Skąd jednak uzyskać przekonanie o tym, jakie są przekonania i zamierzenia ustawodawcy?

Sposobem na to jest według niego przyjrzenie się formie wypowiedzi przepisu prawnego bądź też rozmiarowi związanej z czynem kary. Starając się trzymać perspektywy współczesnego prawa kościelnego, Häring przypomina istniejącą w nim zasadę, że groźba ciężkiej kary ma służyć podkreśleniu tego, jak ważkie jest obowiązywanie danej regulacji w sumieniu. Odpowiednie następstwa karne nie są jednak bodźcem, a jedynie oznaką poważnego obowiązywania. Niemożliwość obłożenia sankcją grzechu ciężkiego jakiejś bagatelnej pod każdym względem sprawy jest, zdaniem niemieckiego moralisty, dość powszechna w nauczaniu moralistów. Wszak samo prawo Boże, jeśli chodzi o rzeczy mało istotne, obowiązuje jedynie lekko. Związanie poważnego obowiązku ze sprawą błahą byłoby niczym więcej jak sidłami zastawionymi na człowieka zmierzającego ku zbawie$\mathrm{niu}^{45}$. Zatem takie prawo stałoby na drodze ku autentycznemu dobru człowieka, z którego to przecież dobra wypływa uzasadnienie praw. Zdarzają się jednak i takie sytuacje, kiedy drobna sprawa, ze względu na wyjątkowy cel oraz osobliwe okoliczności, staje się bardzo istotna i w efekcie może rzeczywiście poważnie obowiązywać ${ }^{46}$.

45 B. Häring, Nauka Chrystusa, dz. cyt., t. I, s. 272.

46 Przykładem może być, wskazuje Häring, zobowiązanie do milczenia. Nierzadko zdarza się, że przez nieuwagę czy roztargnienie nawet drobna niedyskrecja może zniweczyć wielkie plany, projekty bądź po prostu nadszarpnąć ludzkie relacje. 
$Z$ racji tego, że niejednokrotnie władza lepiej przewiduje takie właśnie sprawy, każdy z osobna, chcąc ustalić wagę obowiązywania danej regulacji, powinien zwrócić uwagę zwłaszcza na sposób wyrażania się ustawodawcy. Nieproporcjonalnie wielka szkoda wynikająca z zastosowania się do prawa czysto ludzkiego, w tym kościelnego, jest powodem nieobowiązywania takiej regulacji. Häring dopowiada, że ma na myśli sytuacje, w których na szali spoczywa ludzkie życie, zasadnicza utrata dobrego imienia, szkoda zdrowotna bądź ziemskiego dobra. Strata albo podjęty trud, które są immanentnie i istotowo powiązane z przestrzeganiem prawa, oczywiście nie są powodem, który mógłby usankcjonować zwolnienie od obowiązku, choćby był bardzo poważny. Od zobowiązania prawnego mogłaby zwolnić, zdaniem niemieckiego moralisty, jedynie wielka szkoda, niewspółmierna względem znaczenia prawa ${ }^{47}$.

Wskazuje on także na istnienie takich szczególnych sytuacji, kiedy ceną staje się np. dobro powszechne, życie czy też zbawienie drugiego człowieka (co ma miejsce w przypadku obowiązków żołnierzy czy duchownych). Wówczas, jeżeli naruszenie prawa wiodłoby do poważnego zgorszenia bądź spotęgowania szkody samego przekraczającego ustawę (względem sytuacji, gdyby zachował prawo), także ludzkie regulacje mogą zachować obowiązywalność „pod groźbą utraty zdrowia czy życia, bo dobro ogólne ma pierwszeństwo przed dobrem jednostki”48. Oczywiście, do takiego wniosku Häring dochodzi z zaznaczeniem, że obowiązek tego typu nie płynie z prawa ustanowionego jako takie przez człowieka, lecz z prawa naturalnego lub Bożego.

\footnotetext{
47 B. Häring, Nauka Chrystusa, dz. cyt., t. I, s. 273.

48 Tamże.
} 
Ponadto, rozróżniając wewnętrzne usposobienie i zewnętrzne wykonanie czynu, niemiecki moralista wskazuje, że w pierwszej kolejności zobowiązanie prawne dotyka rzeczywistości zewnętrznej, a dopiero ubocznie należytego usposobienia przy wykonywaniu danego przepisu prawnego. Nie zgadza się jednak z opinią, iż prawo nie miałoby z nastawieniem do jego realizacji nic wspólnego. W takim przypadku okazałoby się, że nie ma jakichkolwiek związków podmiotowego prawa z moralnością, a tymczasem, jak dopowiada, prawo podmiotu stanowi część moralności i jego wewnętrzne dążenie zmierza nie tylko ku maksymalizacji dobra powszechnego, ale też do „umoralnienia poddanych” ${ }^{49}$. Dzieje się tak nawet wówczas, gdy prawodawca podkreśla zewnętrzną regulację, a nie nastawienie, bowiem nie może znikać z horyzontu definitywny sens i cel prawa. Zwłaszcza jeśli chodzi o ustawodawstwo kościelne, zawężanie rozumienia obowiązku prawnego wyłącznie do zewnętrznego aspektu realizacji postrzega Häring jako błąd pars pro toto. Unaocznia swą tezę tym, że skoro prawo podmiotowe i moralność stanowią zasadniczo jedno, to tym bardziej jest tak z przepisami kościelnymi oraz wspólnotą łaski Mistycznego Ciała Chrystusa ${ }^{50}$. I dopowiada: „zewnętrzne prawo kościelne jest na usługach porządku łaski. Nie należy oddzielać zewnętrznego obowiązywania ludzkiego prawa od Zakonu łaski Chrystusowej, które istotnie wymaga wewnętrznego usposobienia"51 . Jako przykład takiej sytuacji w realiach kościelnych przedstawia ocenę zachowania osoby, która poprzez wyłącznie zewnętrzne, poprawne spełnienie obowiązku modlitwy

49 Tamże.

$50 \mathrm{~W}$ tym miejscu ponownie powraca zagadnienie roli modelu pojmowania Kościoła dla teologii.

51 B. Häring, Nauka Chrystusa, dz. cyt., t. I, s. 273. 
brewiarzowej czy uczestnictwa w Eucharystii, bez choćby krzty troski o wewnętrzne ich przeżywanie, zachowuje się jak niewolnik. Próby oceny zewnętrznej realizacji postanowień prawnych jako właściwych i przedstawiania ich jako wzorcowych dla kościelnego prawodawstwa Häring zrównuje ze znieważaniem Kościoła, widzianego wówczas jako rzeczywistość pełna wyłącznie przepisów prawnych. Taki pogląd, jego zdaniem, z góry niweczy immanentną zasadność tworzonych we wspólnocie wiary aktów prawnych $^{52}$.

Wobec tego może słusznie zrodzić się pytanie, czy wyłącznie zewnętrzne wypełnienie regulacji prawnej bez właściwego wewnętrznego usposobienia nie obliguje do powtórzenia go. Zdaniem Häringa, ponowne wykonanie przepisu powinno nastąpić wyłącznie w tych przypadkach, które domagają się należytego usposobienia do prawomocności danego aktu ${ }^{53}$. Zawsze natomiast pozostaje powinność zdobycia należytego usposobienia poprzez żal (jak zaznacza, ów obowiązek zachodzi wyłącznie wobec Boga, nie wobec ludzkiego ustawodawcy). Jako oczywistość postrzega on to, że ani doskonałość, ani nieskazitelna prawość usposobienia przy spełnianiu zobowiązania prawnego w żadnym wypadku nie podlegają obowiązkowi ludzkiego ustawodawstwa. Nawet w perspektywie prawa Bożego nie istnieje wymaganie, by działanie płynęło z niezachwianej cnoty, a jedynie by jej nie uwłaczało oraz istotnie dążyło do jej zdobycia ${ }^{54}$.

52 Tamże, s. 274.

53 Autor ma na myśli choćby zawarcie związku małżeńskiego i zwłaszcza tzw. zgodę małżeńską, ale również przysięgi oraz „pewne umowy” - przy czym nie precyzuje tych ostatnich; zob. tamże.

54 Tamże. 


\subsection{Przedmiot ustawodawstwa ludzkiego}

Jeżeli chodzi o zakres przedmiotowy prawa ludzkiego, to według Bernharda Häringa powinno ono nakazywać wyłącznie „akt (sam w sobie) moralnie dobry lub przynajmniej obojętny" 55 . Niemiecki moralista nie widzi zarazem możliwości, by było to działanie moralnie niewykonalne lub niewspółmiernie skomplikowane. Ze względu na to, że prawo ma obowiązywać ogół, nie wolno tworzyć zobowiązań do rzeczy niezwykłych, tj. działań heroicznych ${ }^{56}$. Dopuszcza przy tym ewentualność, iż prawo może zakazać czynów dobrych samych w sobie lub obojętnych, jeżeli w pewnych warunkach szkodziłyby one dobru wspólnemu ${ }^{57}$.

Omawiając relację między prawem podmiotowym a moralnością, Häring podkreśla, że nie mają one tego samego zadania. O ile bowiem prawo może nieraz tolerować jakieś zło dla uniknięcia większego, o tyle nigdy nie ma kompetencji do uznania zła za coś dozwolonego ${ }^{58}$. Nadto musi z wielką roztropnością unikać jakichkolwiek pozorów tolerowania zła. W kontekście współczesnych debat politycznych na tematy szczególnie istotne i budzące wiele emocji (jak aborcja czy in vitro) ciekawe jest przywołanie obserwacji niemieckiego moralisty, który stwierdził, że prawo tym bardziej powinno wystrzegać się choćby skrytej akceptacji zła, im łatwiej wziąć za moralnie dopuszczalne to, na co prawo zaledwie przymyka oko ${ }^{59}$.

55 Tamże.

56 Są to tzw. czyny supererogacyjne.

57 Szkoda, że autor nie zilustrował w żaden sposób takiego przypadku.

58 Taką sytuację niemiecki moralista opatrzył przykładem z zakresu prawa państwowego, kiedy to władza, chcąc uniknąć „gwałcenia sumienia”, odchodzi od koncepcji powołania bezdusznej policji obyczajowej.

59 B. Häring, Nauka Chrystusa, dz. cyt., t. I, s. 274. 
Rozpatrując zagadnienie należytego usposobienia przy wypełnianiu prawa $\mathrm{w}$ świetle przedmiotu praw ludzkich, Häring z wielką starannością rozróżnia rzeczywistość świecką i kościelną. Ta pierwsza nie ma kompetencji do nakazywania aktów wyłącznie wewnętrznych, bowiem nie jest to niezbędne do realizacji jej celów. Przywołuje on przy tym rzymską zasadę, iż władza państwowa nie ma prawa wymagać ani oceniać nastawienia jednost$\mathrm{ki}^{60}$. Kościół natomiast ma możliwość zobowiązywania do aktów wyłącznie wewnętrznych. Dokonuje się to na dwóch płaszczyznach: forum internum, czyli przez kierownictwo wewnętrzne w sakramencie pojednania, oraz forum internum extra-sacramentale, czyli przez kierownictwo poza sakramentem.

Ponadto, jak zauważa niemiecki moralista, Kościół może nawet $\mathrm{w}$ jakiejś mierze - przez specjalny urząd sędziowski, zajmujący się właśnie sakramentem pokuty (tj. Penitencjaria Apostolska) - osądzać i egzekwować wewnętrzne usposobienie. Za niepewną uznaje on natomiast możność Kościoła regulowania stricte wewnętrznych aktów. Jedynie wtedy, gdy tłumaczone i precyzowane przez Kościół jest prawo Boże, odpowiednia władza może wydać obowiązujące wskazania w odniesieniu do wyłącznie wewnętrznych działań. Poza tym przypadkiem moralista z Böttingen nie dopuszcza żadnych innych.

Akt wewnętrzny działania jest w ocenie Häringa istotny jedynie na tyle, na ile bez niego nie zaistnieje działanie zewnętrz-

60 Chodzi o regułę „De internis non iudicat praetor”. We współczesnym kontekście, zauważa Häring, oskarżony pytany o swe nastawienie czy stanowisko wewnętrzne nie ma obowiązku udzielania jakiejkolwiek odpowiedzi. Nawet jeśli jest ono niezbędne do wykonania prawa, to i tak „w żadnym wypadku poddany nie musi odpowiadać za to przed władzą świecką"; tamże, s. 275. 
$n e^{61}$. Natomiast Kościół bierze pod uwagę zwłaszcza ostateczny cel swego istnienia, jakim jest zbawienie człowieka, i właśnie dlatego domaga się także aktów wewnętrznych: „zawsze ze względu na pomnożenie łaski w Królestwie Bożym"62. Za charakterystyczne uważa on to, że bezpośrednim przedmiotem powinności prawnej w Kościele jest akt zewnętrzny, z kolei nastawienie wewnętrzne jest pośrednim przedmiotem zobowiązania. W tych jednak przypadkach, kiedy actus internus stanowi o ważności lub też o pełnym wypełnieniu prawa, jest on obowiązkowy dokładnie tak samo jak actus externus, a zatem bezpośrednio. Przykładem takiej sytuacji są, według niemieckiego moralisty, przepisana intencja kapłana odprawiającego Mszę oraz właściwe nastawienie przy wypełnianiu zobowiązania do wielkanocnej spowiedzi i komunii. Jeżeli w tych sytuacjach zabrakłoby aktu wewnętrznego, wówczas należałoby, w miarę możności, to prawo jako całość ponownie wypełnićc ${ }^{6}$.

\section{Okoliczności zwalniające od posłuszeństwa prawu}

Najprostszym z możliwych przypadkiem zwolnienia od obowiązującego prawa jest usunięcie się osoby podlegającej mu od przynależności do ustawodawcy bądź oddalenie się z miejsca, w którym jakieś prawo obowiązuje ${ }^{64}$. W takim wypadku człowiek nie

61 Choćby wtedy, gdy żołnierz składa przysięgę i powinien mieć rzeczywiście intencję wypełnienia wypowiadanych słów.

62 B. Häring, Nauka Chrystusa, dz. cyt., t. I, s. 275.

63 Tamże.

64 Zdaje się, że w przypadku rzeczywistości świeckiej można by tu pomyśleć o zmianie obywatelstwa (utracie lub rezygnacji) bądź emigracji. 
podlega przepisanemu zobowiązaniu ${ }^{65}$. Ponadto, w sytuacji tak zawinionego, jak i niezawinionego niewypełnienia prawa w określonym czasie, z którym to prawo jest ściśle związane, nie zachodzi zobowiązanie prawnego świadczenia ${ }^{66}$. Tymczasem czyn niezależny w swej istocie od terminu, a związany z nim tylko pośrednio tak, by z pewnością doszło do jego wypełnienia, obowiązuje - jak uważa Häring - nadal, i to nawet podwójnie ${ }^{67}$. Nie jest jasne, co autor ma na myśli, mówiąc o „podwójnej” obowiązywalności takiego czynu (zdaje się, że bardziej chodzi o podkreślenie bezzwłocznej konieczności realizacji przykazania aniżeli podwójne jego wykonanie); nie odnosi się on również do zasadności związania dorocznego zobowiązania do sakramentu pokuty w okresie wielkanocnym z jego teologiczno-duchową treścią.

Kolejny przypadek zwolnienia $\mathrm{z}$ obowiązywania prawa stanowią dla Häringa niemożność fizyczna i moralna, które w zupełności uwalniają sumienie od zobowiązania. Jeżeli jednak wypełnienie powinności prawnej wskutek opóźniania świadczenia okaże się w późniejszym czasie niemożliwe, to powinno się wykonać dany akt uprzednio, gdy tylko zaczął on obo-

65 Przykładem jest przemieszczenie się z terenu jednej diecezji, w której nakazany jest post, do innej, w której to przykazanie nie istnieje. Ten kazus Häring uznaje za dopuszczalny pod warunkiem szlachetności motywów, jakimi kieruje się jednostka, decydując się na taki krok.

66 Dla zilustrowania tego przypadku niemiecki moralista podaje sytuację osoby zobligowanej do modlitwy brewiarzowej. Jego zdaniem, ów obowiązek po minięciu północy nie obowiązuje (względem modlitwy z dnia poprzedniego). Trzeba jednak wziąć pod uwagę, że ma on tu na myśli nieaktualny już porządek prawny, tj. układ brewiarza i związane z nim regulacje przed reformami Soboru Watykańskiego II; zob. B. Häring, Nauka Chrystusa, dz. cyt., t. I, s. 280.

67 Właściwą ilustracją tego przypadku jest spowiedź wielkanocna. 
wiązywać $^{68}$. Z tym zagadnieniem autor powiązał też aspekt świadomościowy i stwierdził, że nieświadomość niepokonywalna uwalnia od prawa, a zasadniczo także od kary. W rozważaniach nie pomija on jednak i takich sytuacji, kiedy to kary okazują się słuszne tylko w przypadku stricte "prawnej” winy, a nałożenie sankcji wskazane dla dobra ogólnego. Krótko mówiąc, chodzi o świadczenie mające na celu odbudowanie porządku prawnego dla zabezpieczenia powszechnego dobra ${ }^{69}$. Z kolei nieświadomość zawiniona, którą dałoby się łatwo pokonać, nie zabezpiecza przed winą i zazwyczaj również przed karą. Ustawy kościelne, jak doprecyzowuje niemiecki moralista, warunkują dużą część przede wszystkim ciężkich kar tym, czy podlegający prawu choćby pobieżnie orientował się w powadze tego prawa, jak też w jego sankcjach. Ostatni zaś typ nieświadomości, wynikającej ze złej woli, nie uwalnia od winy ani od kary ${ }^{70}$. Wobec

68 Po raz kolejny Häring odwołuje się do modlitwy brewiarzowej. W tej sytuacji, jeśli poddany prawu wieczorną porą nie będzie miał dostatecznie dużo czasu, by odmówić przepisane modlitwy, zobowiązany jest do wykonania tego odpowiednio wcześniej. Aczkolwiek jeżeli przewidywałby, że trudności pojawią się kolejnego dnia, to wówczas nie jest obowiązany do uprzedniego wypełnienia obowiązku. Ponadto autor przywołuje pogląd, zgodnie z którym nie poleca się odmawiania modlitwy na zakończenie dnia w porze rannej lub południowej, nawet jeśli zachodzą obawy, że zabraknie na nią czasu wieczorem.

69 Jurydyczną podbudową dla sankcji nakładanych w przypadku winy wyłącznie prawnej jest jedynie domniemanie prawne bądź fikcja prawna, że podlegający prawu w sposób zawiniony nie posiadał odpowiedniej wiedzy na temat danego zakresu prawa. Choć autor nie podaje tu żadnego przykładu, zdaje się, że mogłoby posłużyć za takowy niezbyt poważne naruszenie reguły zakonnej przez nowicjusza.

70 To tzw. ignorantia affectata, która w potocznym języku najczęściej bywa wyrażana słowami: „nie chciałem/am tego wiedzieć”; B. Häring, Nauka Chrystusa, dz. cyt., t. I, s. 280. 
stosowanej niekiedy wymówki o zawinionej nieznajomości prawa zaczęto tworzyć przepisy, które - ustanawiając jakiś obowiązek pod karą nieprawomocności jakiegoś aktu - nie uznają jej.

Inną drogą wiodącą do zwolnienia od posłuszeństwa prawu jest ustanie obowiązku prawnego. Może ono nastąpić - najczęściej - przez oficjalne, całkowite lub częściowe odwołanie prawa przez upoważnionego do tego prawodawcę, wskutek czego nowy porządek prawny unieważnia wszelkie wcześniejsze regulacje niedające się zintegrować $\mathrm{z}$ nowymi. $\mathrm{Z}$ utworzenia nowego porządku prawnego w jakiejś dziedzinie wynika jednak nie tylko wygaśnięcie obowiązków, ale, jak zaznacza Häring, również wszelkich wcześniejszych praw ${ }^{71}$. Poza oficjalnym cofnięciem praw przez ustawodawcę istotne jest także ustanie ich mocy obowiązującej w następstwie „wygaśnięcia ich sensu i celu”72. Jak wskazuje moralista $\mathrm{z}$ Böttingen, kiedy prawo przestało mieć dla społeczności jakiekolwiek znaczenie lub nawet stało się szkodliwe, bądź gdy celu zamierzonego przez prawodawcę nie można już w jakikolwiek sposób osiągnąć, wówczas przestaje ono istnieć, ewentualnie chwilowo nie obowiązuje. Jednak dopóki występuje przynajmniej jeden z celów prawa, dopóty trwa ono samo i płynące z niego zobowiązanie.

71 W razie wątpliwości nie powinno się uznawać odwołania starych regulacji prawnych za obowiązujące; trzeba natomiast wszelkie późniejsze akty prawne tłumaczyć w sposób możliwie najbardziej zgodny z uprzednimi przepisami.

72 B. Häring, Nauka Chrystusa, dz. cyt., t. I, s. 281. 


\section{Dyspensa jako wolne od winy działanie rozmijające się z wykładnią prawa}

Istotnym przypadkiem ustania bezpośredniego obowiązku prawnego w pewnych sytuacjach jest dyspensa, środek prawny, który - jak wskazuje Remigiusz Sobański - istnieje w Kościele od dawna. „Szczyci się więc dawną i charakterystyczną dla prawa kościelnego tradycją" ${ }^{\text {"3 }}$. W odróżnieniu od przywileju nie jest ona rodzajem długotrwałego uprawnienia. Jak wyjaśnia Häring, ze względu na fakt, że prawa tworzone są dla dobra ogółu, w przypadku pewnych osób czy w niektórych sytuacjach prawodawca ma możliwość, a nieraz nawet obowiązek, udzielenia dyspensy. Jaki jest tego powód?

Warto w tym miejscu oddać głos Sobańskiemu, biegnącemu myślą ku sytuacjom, w których uwarunkowania osobowe, lokalizacyjne, czasowe, jak też dobro Kościoła mogą motywować działanie rozmijające się z wykładnią prawa ${ }^{74}$. Są to zdarzenia dość wyjątkowe, kiedy dozwolone staje się zachowanie zakazane przez prawo lub zachodzą okoliczności uzasadniające odstąpienie od realizacji jakiegoś nakazanego ustawowo postępowania. Zapewne Sobański zgodziłby się w tym względzie z Häringiem, jak bowiem wskazuje, okazałoby się dla praw bardzo szkodliwe, gdyby

73 Zdaniem polskiego kanonisty, wydarzeniem o dużym znaczeniu dla instytucji dyspens było motu proprio papieża Pawła VI De Episcoporum muneribus, AAS 58 (1966). Rozdział VIII przyznaje biskupom władzę udzielania dyspens od norm prawa powszechnego. O ile bowiem od prawa Bożego dyspensować może - zgodnie $\mathrm{z}$ tradycją prawa kanonicznego oraz owym dokumentem - wyłącznie papież, o tyle władza udzielona obecnie biskupom stanowi środek prawny dający możliwość wzglądu na szczególne, nieraz bardzo trudne sytuacje ludzi; zob. R. Sobański, Kościół - prawo - zbawienie, dz. cyt., s. 286.

74 Tamże. 
to jednostka miała w całej rozciągłości decydować o zwalnianiu od istotnych przepisów (nawet w sytuacjach wątpliwych). Ustawodawca musi wziąć pod uwagę realia, które, zdaniem niemieckiego moralisty, jasno wskazują, iż nie każdy odznacza się cnotą epikei na poziomie doskonałym. Zaznacza on przy tym, że w sytuacjach wątpliwych nie ma mowy o powołaniu się właśnie na tę cnotę. Z tego też względu rozważne korzystanie $\mathrm{z}$ dyspensy jest, według niego, koniecznością prawa. Szczególnie wtedy, gdy na szali spoczywa prawo istotniejsze, jak i w sytuacji niemożliwości osiągnięcia pewności co do zaistnienia przyczyn uzasadniających zwolnienie od posłuszeństwa prawu lub w następstwie posłużenia się epikeią, nie ma, jego zdaniem, innej możliwości, jak tylko zwrócenie się z prośbą o dyspensę do kompetentnej władzy.

Ważką rolę w udzielaniu dyspensy odgrywa wystarczająca przyczyna, na co wskazują zarówno Häring, jak i Sobański. Jak precyzuje polski kanonista - jest nią dobro duchowe wiernych ${ }^{75}$. To ono stanowi powód, dla którego poddany prawu może zostać zwolniony z określonego zobowiązania. Czy wobec tego dobro duchowe stoi ponad prawem? Zdaniem Sobańskiego - tak, jeżeli mamy na myśli konkretny przepis. Rozpatrując jednak cały kontekst prawniczy, polski kanonista zwraca uwagę na fakt, że dyspensa zawiera się w prawie, jako że to ono samo wykształciło taki środek umożliwiający jego realizację, mimo że dane zachowanie będzie przeciwne ustawie. Zatem instytucja dispensatio nie stoi ponad prawem in genere ${ }^{76}$. Nie jest ona, jak utrzymuje Sobański, szkodą w stosunku do ustawy, ale metodą stosowania prawa przynależącą do życia Kościoła. Chodzi o to, by każdy wierzący

75 Zaznaczone jest to również we wspomnianym wyżej motu proprio Pawła VI, za: R. Sobański, Kościół - prawo - zbawienie, dz. cyt., s. 286.

76 Tamże, s. 287. 
mógł odnaleźć się w rzeczywistości prawnej Kościoła i aktywnie uczestniczył w życiu tej wspólnoty, mimo skomplikowania swojej sytuacji egzystencjalnej.

Co jednak w przypadku, gdy brakuje przekonania o zaistnieniu słusznej przyczyny? Udzielenie wówczas dyspensy Häring ocenia dość surowo - jako grzeszne ${ }^{77}$. Co więcej, gdyby okazało się, że przełożony nie posiada kompetencji prawodawcy i zajmuje na dodatek niższe stanowisko, dyspensa byłaby nieprawomocna. Podobny skutek miałaby dyspensa otrzymana na podstawie nieprawdziwych argumentów. Wraz z ustaniem powodów dla dyspensy mającej moc prawną ustaje również ona sama. Natomiast w przypadku dubium dyspensa zachowuje ważność i jest dozwolona.

\section{Epikeia jako zachowywanie ducha prawa}

Ostatnim, szczególnym przypadkiem ustania obowiązywalności prawa jest cnota epikei. Współczesna charakterystyka epikei budowana jest zazwyczaj na podstawie definicji Tomaszowej ${ }^{78}$. W rozważaniach poświęconych głównym pojęciom z zakresu moralności właśnie od tej strony ujął ją niemiecki teolog Franz Böckle. Oparł się on namyśli Akwinaty, określającego epikeię jako cnotę, która w razie odejścia od literalnego brzmienia przepisu zwraca się ku temu, co najlepiej odpowiada sprawiedliwości

B. Häring, Nauka Chrystusa, dz. cyt., t. I, s. 282.

8 O epikei dyskutowano już wcześniej. Arystoteles w swej Etyce nikomachejskiej i Retoryce zapisał stwierdzenia, które do dziś uznaje się za klasyczne. Niejednokrotnie są one punktem wyjścia w analizowaniu sprawiedliwości, słuszności i prawa; zob. Arystoteles, Etyka nikomachejska, Warszawa 2008, ks. V, 10, 1137 b, s. 189-190. 
i dobru powszechnemu ${ }^{79}$. Kierując się takim założeniem, Böckle dodał, że epikeia, najlepsza interpretatorka prawa, dąży w przypadku prawa pozytywnego do osiągnięcia pełni sprawiedliwości w miejsce czystego legalizmu. Daje ona prywatną, własną interpretację prawa, która w konkretnej sytuacji z samej rzeczy wywodzi zobowiązanie co do tego, czego chce prawo, nieraz wbrew dosłownemu jego brzmieniu. Takie podejście jest, według Böcklego, lepsze niż prosta, literalna zgodność z przepisem ${ }^{80}$. Jeśli chodzi o charakter takiego sądu, to jak dodaje ów moralista, w tego typu sytuacjach oczywiście wymagane jest, by osąd co do wyjątku był pewien ${ }^{81}$.

Nieco podobnie, aczkolwiek z innej perspektywy, przedstawia epikeię Remigiusz Sobański. Opisując normatywny porządek prawny w Kościele, polski kanonista wskazuje na istnienie takich sytuacji egzystencjalnych, które nie dają się wciągnąć w życie wspólnoty według dosłownego brzmienia zapisu prawnego. Zdarza się bowiem, że zawarty w kanonach tok działania może się okazać dla kogoś niemożliwy do realizacji. Kiedy pewna norma z pozoru, czyli według zapisu, zdaje się słuszna, ale faktycznie jej zastosowanie nie buduje i nie umacnia wspólnoty, polski kanonista mówi o normach korygujących ${ }^{82}$. Wówczas dana osoba poprzez subiektywny sąd zauważa, że osobliwość okoliczności, w jakich się znalazła, nie została przewidziana przez prawodawcę. Gdyby tak się stało, wydałby on inne zarządzenie. Na podstawie tego sądu osoba może uznać się za zwolnio-

79 Tomasz z Akwinu, S.Th. II-II, q. 120, a. 1-2.

80 F. Böckle, Grundbegriffe der Moral, Aschaffenburg 1977, s. 65.

81 Tamże.

82 R. Sobański, Kościół - prawo - zbawienie, dz. cyt., s. 284. 
ną od zobowiązania wobec danej normy jako nieodpowiadającej konkretnym realiom.

W rozważaniach Sobańskiego widać stanowcze przeciwstawienie się takiemu rozumieniu tej cnoty, jakoby była ona przejawem chęci uwolnienia się od prawa i obowiązku nakładanego przez zapis prawny ${ }^{83}$. Jako ośrodek epikei i kryterium dla jej zastosowania wskazuje on dobro wspólne, o które troska może się nieraz wyrażać wbrew literalnemu charakterowi normy ${ }^{84}$. Warto zwrócić przy tym uwagę na subiektywność sądu wyrabianego przez jednostkę, którego to sądu - jak się zdaje - nie można umiejscowić gdzie indziej, jak właśnie w sumieniu, co może kierować uwagę na zagadnienie kreatywności sumienia ${ }^{85}$.

$\mathrm{W}$ przypadku kiedy ustawa wydana $\mathrm{z}$ zamiarem realizacji i rozwoju wspólnoty wcale nie zbliża ku temu celowi, posłużenie się epikeią jest, zdaniem Sobańskiego, przejawem dojrzałości chrześcijańskiej i współodpowiedzialnej mądrości w urzeczywistnianiu istoty kościelnego prawa. Jak zauważa, doświadczenie nauki i praktyki kościelnego ustawodawstwa zawsze przepojone było świadomością, że czasem do celu stawianego przez prawo można dojść, jedynie działając wbrew jego literze. Właściwe pojmowanie epikei, a także jej założeń, stanowi integralną

83 Tamże, s. 285.

84 Odwołuje się przy tym, podobnie jak F. Böckle, wprost do myśli św. Tomasza, zob. S.Th. II-II, q. 120, a. 2, ad. 2.

85 Propozycją wartą przywołania jest rozumienie sumienia przedstawione przez Josefa Fuchsa. Stoi ono w opozycji do statycznego i legalistycznego podejścia, które - jego zdaniem - cechowało etykę scholastyczną. Wysunął on rozumienie sumienia jako uzdolnienia osobowego i dynamicznego, które wyraża indywidualność i „osobową niepowtarzalność każdego podmiotu"; zob. J. Merecki, Spór o prawo naturalne. Analiza modelu argumentacji etycznej Josefa Fuchsa, Lublin 2001, s. 100. 
część eklezjalnej świadomości prawnej i jest jednym z elementów kształtujących postawę chrześcijanina względem przepisów prawa kościelnego.

Odmienne tło dla prezentacji epikei tworzy natomiast Josef Ziegler ${ }^{86}$. Jego zdaniem, w przepowiadaniu chrześcijańskim mało miejsca poświęcano dotychczas cnocie słuszności. Jej istnienie zaznacza się szczególnie wówczas, gdy sumienie określa $\mathrm{z}$ pewnością, że konkretny przepis (na podstawie swego wewnętrznego związku z porządkiem bytu) w obecnych okolicznościach nie obowiązuje co do słowa; stąd też pewny sąd sumienia ma pierwszeństwo przed tekstem prawa ${ }^{87}$. Cnoty epikei Ziegler nie chce jednak widzieć wyłącznie w wąskim kontekście tradycyjnie przytaczanych sytuacji: drobnej kradzieży, np. jedzenia, czy też potajemnego zadośćuczynienia. Jest ona, jego zdaniem, jak każda cnota: powszechnie obowiązującą, stale konieczną do zdobywania formą urzeczywistniania miłości do Boga, Stwórcy i Zbawiciela. Niesie ona ciężar wiedzy tego, że nie każde obowiązujące prawo jest zawsze i pod każdymi warunkami wiążące. Przez to, jak utrzymuje Ziegler, przyczynia się do tego, że nierygorystyczne posłuszeństwo prawu nie zmienia się w najwyższe bezprawie, według aksjomatu: najwyższe prawo najwyższym bezprawiem (summum ius, summa iniuria). Wewnętrzna moralność stoi ostatecznie ponad zewnętrzną legalnością ${ }^{88}$.

Jeżeli chodzi o rozumienie epikei, Ziegler dostrzega wielką zasługę w szczególnym podejściu do tej cnoty, jakim odznaczał

\footnotetext{
86 J. Ziegler, Vom Gesetz zum Gewissen, dz. cyt., s. 62.

87 Jak wskazuje Ziegler, zakaz kradzieży straciłby sens, gdyby ktoś umarł z głodu, powstrzymując się od spożycia jedzenia należącego do innego człowieka.

88 J. Ziegler, Vom Gesetz zum Gewissen, dz. cyt., s. 63.
} 
się Albert Wielki. W przeciwieństwie do Arystotelesa i większości systematyków scholastycznych, objaśniał on ją nie jako wykładnię woli ludzkiego prawodawcy, ale odnosił ją - bardziej radykalnie - do woli boskiego prawodawcy i tłumaczył jako zgodność prawa z porządkiem bytów, z ratio legis. Epikeia wobec tego ma swe granice tam, gdzie bez jakichkolwiek wątpliwości stawką jest boskie prawo zakotwiczone w zwyczajowym prawie naturalnym albo w boskim prawie pozytywnym ${ }^{89}$. Tylko główny nakaz miłości bliźniego pozwala, zdaniem Zieglera, aprobować w decydujących przypadkach skrajnych zachowawczość, postawę zorientowaną na pewną, możliwie największą zgodność z prawem, jako jedynie stosowną i rozsądną. Może wszakże zdarzyć się i tak, że ktoś czuje się zobowiązany w sumieniu uczynić więcej, aniżeli wymaga litera prawa.

Z rozważań nad cnotą epikei wynika dla Zieglera także to, że człowiek skrupulatny nie powinien bezmyślnie dać się ponieść radości $\mathrm{z}$ dosłownego wypełnienia prawa ${ }^{90}$. Autor wskazuje, że dla dokładnego postępowania osobiste ukształtowanie osądu w procesie myślowym jest nie tylko dozwolone, ale wręcz nakazane. Bytowo ugruntowana struktura prawa ma konsekwencje dla każdego, kto chciałby postrzegać je w całej rzetelności.

Struktura chrześcijańskiej moralności, której celem jest upodobnienie się do Chrystusa, jest w swej istocie odpowiedzią na Boże wezwanie i łaskę, niezbędną do realizacji przemiany w nowego człowieka ${ }^{91}$. W ramach tej moralności odpowiedzialność

89 Ziegler podkreśla, że są to m.in. zobowiązania, które wypływają $\mathrm{z}$ naturalnych lub nadnaturalnych motywów chęci pomocy $\mathrm{w}$ zbawieniu bliźniego, np. w zagrożeniu życia lub przy udzielaniu sakramentów.

90 Tamże.

91 Por. Ga 3, 27n. 
jednostki przesunięta zostaje $\mathrm{z}$ zewnętrznego, nierozważnego dostosowania się do zinstytucjonalizowanej formy państwowych i kościelnych praw na poziom osobistej decyzji ${ }^{92}$. Jednostka, którą w takiej sytuacji widzi Ziegler, musi być bezwarunkowo wierzącym i bezinteresownie kochającym człowiekiem. Musi on jasno zdawać sobie sprawę, że przyjdzie mu jednorazowo i niezastępowalnie złożyć sprawozdanie przed sądem Boga, czy był wierny nakazowi chwili ${ }^{93}$. Ziegler żywi przekonanie, że prawo musi być afirmowane przez jednostkowe sumienie świadomie, tym bardziej że właściwa odpowiedź na wezwanie Boga może być dana przez ochrzczonego tylko jako członka mistycznego Ciała Chrystusa, Kościoła. Taki stan rzeczy zarazem ułatwia i utrudnia sąd sumienia względem prawa. Ostatecznie, jak zauważa Ziegler, jawi się potrzeba formacji sumienia:

(...) skoro przy cnocie epikei na osąd sumienia przypada cały ciężar wykazania racji wystarczającej, powołanie się na nie wymaga osobowego kształtowania sumienia, i to niemałej miary. Kształtowanie sumienia jest kształtowaniem do rzeczowości, do poznania i uznania ustanowionej przez Boga rzeczywistości ${ }^{94}$.

92 J. Ziegler, Vom Gesetz zum Gewissen, dz. cyt., s. 64.

93 Warto przytoczyć tu koncepcję Alaina Badiou, który stworzył i rozwinął ideę konieczności wierności wydarzeniu; tylko postawa wierności wobec wydarzenia stanowi dlań drogę ku budowaniu własnej podmiotowości. Interesujące w jego myśli jest też spojrzenie na nieśmiertelność człowieka, której nie stwierdza, ale której istnienie dopuszcza (będąc zarazem zdeklarowanym ateistą). Zdaniem Badiou, nieśmiertelność jest właściwością wyróżniającą człowieka na tle innych istnień, obecną choćby w matematyce. Dogłębną analizę poglądów Francuza na temat wierności wydarzeniu przedstawiła Sylwia Kłosowicz, O wierności wydarzeniu. Studium na temat pogląów etycznych Alaina Badiou, Warszawa 2016 (znaczenie wydarzenia w stawaniu się podmiotem moralnym oraz znaczenie nieśmiertelności dla tego procesu autorka opisuje przede wszystkim w rozdziale IV).

94 J. Ziegler, Vom Gesetz zum Gewissen, dz. cyt., s. 64. 
Natomiast Bernhard Häring w opisie epikei sporo miejsca poświęca na analizę historycznego rozwoju pojmowania tej cnoty i w tych rozważaniach sięga do Arystotelesa, Akwinaty, św. Alfonsa Liguoriego i Sáncheza. Spojrzenie w przeszłość pozwoliło mu wyrobić sobie własny ogląd. W tonie dość podobnym do przywołanych wyżej autorów powiada on, że cnota epikei pozwala uczniowi Chrystusa szukać adekwatnego znaczenia prawa, które ludzkim przepisom, niedoskonałym i niewystarczającym właśnie ze względu na ich twórcę, nadaje żywotne odniesienie do Chrystusa. Swoiste u Häringa jest jednak to, że fakt niedostateczności prawa ludzkiego i poniekąd konieczność epikei uznaje on za coś, co chrześcijanin może postrzegać jako czynnik wspierający rozwój jego dojrzałości ${ }^{95}$. W przekonaniu niemieckiego moralisty ta niewystarczalność skutecznie odciąga nas od czysto zewnętrznego zachowywania ludzkiego prawa oraz czysto ludzkiej służalczości w wypełnianiu go ${ }^{96}$.

\section{Posłuszeństwo względem przełożonych}

Zagadnieniem obowiązywalności dyspozycji wydawanych przez przełożonego znajdującego się w stanie grzechu zajmowano się tak naprawdę od zarania chrześcijaństwa, pierwotnie w odniesieniu do ważności sakramentów sprawowanych przez grzesznych szafarzy. A jeśli chodzi o dyspozycje wydawane np. przez odpowiednią władzę klasztorną zakonnikowi? Czy zawsze należy

95 B. Häring, Nauka Chrystusa, dz. cyt., t. I, s. 267.

96 O potrzebie odchodzenia od legalizmu, jak również o „niezupełnym” prymacie sumienia nad prawem w świadomości katolickiej zob. J. Ziegler, Vom Gesetz zum Gewissen, dz. cyt., s. 64-65. 
dawać im posłuch? Co jest właściwym kryterium oceny otrzymywanych poleceń?

Jak wskazuje moralista $\mathrm{z}$ Böttingen, nie cnotliwość prawodawcy, ale prawowitość jego władzy oraz słuszność wydawanych dyspozycji implikuje obowiązek posłuszeństwa wobec nich ${ }^{97}$.

\subsection{Przypadki nieposłuszeństwa autorytetowi}

Skoro sumienie nie rodzi prawdy samo z siebie i nie tworzy jej, ale jako uzdolnienie człowieka ma tę właściwość, że inspiruje wolę do uzgadniania siebie $z$ odkrywaną prawdą i do poszukiwania tejże przed podjęciem decyzji, to związek sumienia i obiektywnej prawdy jest niezaprzeczalny. Jak do rozpoznania i uznania przez jednostkę prawdy, z której będą wynikały jej konkretne postawy, ma się postać przełożonego, występującego $\mathrm{z}$ właściwym sobie autorytetem?

W perspektywie chrześcijańskiej, zauważa Häring, „sumienie i uczący nas Bóg łączą się ściśle z sobą" ${ }^{\text {". }}$. Pouczanie i kierownictwo, bez którego sumienie nie może się obyć, dokonuje się zwłaszcza przez jego kontakt z porządkiem spotykanym we wszechświecie ${ }^{99}$, a w sposób najdoskonalszy w spotkaniu z Chrystusem. Z Jego woli dokonuje się to także przez Ducha

97 Häring odwołuje się w tym kontekście do rozwiązań z okresu nowożytnej działalności Kościoła. Wskazuje treści, które powstały w odpowiedzi na propozycje reformatorów: Husa i Wiklifa, a które znaleźć można w: H. Denzinger, Enchiridion symbolorum definitionum et declarationum de rebus fidei et morum, Freiburg im Br. 1991, p. 595 i 656, za: B. Häring, Nauka Chrystusa, dz. cyt., t. I, s. 272.

98 Tamże, s. 165-166.

99 Wszak osoby niewierzące także mają sumienie i one również powinny je kształtować, tak by mogło właściwie rozpoznawać prawdę. 
Świętego w Kościele. I to jest właściwy punkt zakotwiczenia ludzkiego autorytetu, który na wzór Bożego odwołuje się do sumienia. W przypadku wspólnoty wierzących jest to nie tylko sumienie rozwijane w oparciu o prawo natury, ale też wysublimowane przez łaskę. Z perspektywy chrześcijańskiej antropologii, jak sumieniu niewierzącego nie jest obce pouczenie zawarte w objawieniu natury, tak dla sumienia wierzącego czymś normalnym jest wsłuchiwanie się w słowo objawione głoszone przez Kościół. Trudności stojące przed wierzącym, związane z otwarciem się na perspektywę wyznaczaną przez wiarę, nie zostają bynajmniej przez autora Nauki Chrystusa pominięte. Rozpatruje on je jako przerażenie „starego człowieka”, zdającego sobie sprawę z zawiłości wiary oraz powagi posłuszeństwa, którego się ona od niego domaga.

Jeżeli chodzi o nieraz głośne sytuacje publicznego odrzucania nieomylności autorytetu nauczycielskiego Kościoła w imię wolności sumienia, to zdaniem Häringa, takie przypadki moga mieć miejsce tylko wtedy, gdy dochodzi do zupełnego rozminięcia się z tym, czym faktycznie jest sumienie. Czymś słusznym byłoby odrzucenie obiektywnego autorytetu (wskazując jako powód jego sprzeczność z sumieniem) tylko wtedy, gdyby było ono rzeczywiście w swej naturze stwórcze i w pełni nieomylne. Ze względu jednak na to, że jest ono sądem rozumu praktycznego człowieka i jest ściśle związane z ludzkim poznaniem, może być błędne. Stąd też dogmat wiary mówiący o zasadniczej nieomylności Kościoła i Biskupa Rzymu nie marginalizuje znaczenia sumienia, ale daje mu niezawodną orientację w sprawach ostatecznych. Dokładne wyznaczenie granic tej nieomylności określa ramy, w których sumienie znajduje się pod całkowicie pewnym 
kierownictwem, a poza którymi może dojść do rozbieżności między „sumieniem a omylnym, lecz prawnie rządzącym autorytetem władzy Kościoła"100.

Właśnie ze względu na świadomość Kościoła co do granic własnej nieomylności jego władza nie tworzy wymagań poza nimi, wykraczających poza zakres właściwego obowiązku troski o ortodoksję wiary ${ }^{101}$. Jeśli chodzi o sprawy dyscyplinarne, to jak wskazuje Häring - może dojść do otwartego konfliktu między zdaniem Kościoła a sumieniem jednostki ze względu na to, że autorytet Kościoła nie zawsze wybiera to, co najlepsze.

Te odważne zdania nie pozwalają jednak na utrwalenie się wątpliwości co do wyważenia poglądów niemieckiego moralisty ${ }^{102}$. Jednym tchem wskazuje on bowiem na specyfikę sądu sumienia jednostki, którego nieomylności może ona być jeszcze mniej pewna aniżeli nieomylności sądu wyrażonego przez instytucję Kościoła. Obopólne przeświadczenie o tych właśnie ograniczeniach własnej bezbłędności prowadzi najczęściej, dopowiada Häring, do rozładowania napięcia. Zasadniczo trzeba uprzednio przyjąć kompetencję autorytetu kościelnej władzy w zakresie prawa i prawdy. Jednakże warunkiem tego jest, według niemieckiego moralisty, prawowitość przedstawiciela władzy Kościoła oraz to, że dana osoba w pełnieniu swojego urzędu odznacza się odpowiedzialnością religijno-moralną. Podlegający prawu musi mieć należyte podstawy dla sądu swojego

100 B. Häring, Nauka Chrystusa, dz. cyt., t. I, s. 166.

101 O obowiązku posłuszeństwa w stosunku do nauczycielskiego urzędu Kościoła zob. tamże, t. II, s. 62-65.

${ }^{102}$ Z pewnością jednak możemy odczytywać je w szczególny sposób, kiedy uwzględnimy jego późniejszy konflikt z Magisterium Kościoła, którego opis, włącznie z procesem, podaje A. Karaś, Człowiek u podstaw odnowy teologii moralnej..., dz. cyt., s. 72-74. 
sumienia, by mógł zakwestionować prerogatywy przysługujące władzy. Häring nie waha się jednak przed dobitnym stwierdzeniem, że w przypadku skrupulatnej analizy samego siebie, kiedy jednostka zbuduje zdecydowany i mocny sąd sumienia, nie może okazać posłuszeństwa na przekór temu stanowisku ${ }^{103}$.

Jeżeli chodzi o zapatrywania Bernharda Häringa na zakres wolności sumienia $\mathrm{w}$ relacji do posłuszeństwa, którym powinno się ono odznaczać, to trzeba stwierdzić, że w żadnym przypadku nie absolutyzuje on tej wolności. W jego mniemaniu sąd rozumu praktycznego nie wyzwala nas od prawa; dopiero on należycie podporządkowuje nas prawu dobra. Bez dłuższych wywodów niemiecki moralista zgadza się z jednej strony z koniecznością wierności względem sumienia, by czynić to, co uzna się za dobre $\mathrm{w}$ ramach swojego poznania oraz adekwatnie do cnotliwego pragnienia poszukiwania dobra. $Z$ drugiej natomiast podkreśla istnienie takich elementarnych zasad moralnych, których znajomością powinien odznaczać się każdy człowiek. Kto od nich odchodzi, ten nie ma - jego zdaniem - prawa do powoływania się na sumienie ${ }^{104}$.

Błądzenie niezawinione utrzymuje prawo i obowiązek jednostki do zachowania zgodności czynów z sumieniem. Może się jednak nieraz zdarzyć tak, że w przypadku błędu przeciw postępowaniu jednostki będzie musiała wystąpić społeczność. Jak wskazuje moralista z Böttingen, są sytuacje, kiedy nie uda się

103 Autor zadaje także pytanie warte przywołania, a dotyczące przypadku, kiedy sumienie ma istotne wątpliwości w stosunku do prawowitości władzy bądź względem moralnej prawości wydanego przez nią rozkazu. Ocenia tę kwestię jako jedną z najbardziej kłopotliwych dla systemu moralności; zob. B. Häring, Nauka Chrystusa, dz. cyt., t. I, s. 167, por. też s. 187-195.

104 Tamże, s. 167. 
w inny sposób zapobiec złym skutkom działalności jednostki. Ewentualne konflikty, które wystąpią w wyniku takiej interwencji, określa on jako tragiczne ${ }^{105}$. Jeżeli jednak błąd okaże się zawiniony, wówczas człowiek nie ma prawa opierać się na wolności sumienia z tego względu, że władza ma za zadanie odciągnąć go od błędu, a społeczność obronić przed nieszczęśliwymi skutkami szkodliwych pomyłek.

105 Próżno szukać w rozważaniach Häringa konkretnego przykładu takiej sytuacji. 